2015-02-01

\title{
What remains of the intersubjective?: on the presencing of self and other
}

Simpson, Paul

http://hdl.handle.net/10026.1/5009

10.1016/j.emospa.2014.04.003

Emotion, Space and Society

Elsevier BV

All content in PEARL is protected by copyright law. Author manuscripts are made available in accordance with publisher policies. Please cite only the published version using the details provided on the item record or document. In the absence of an open licence (e.g. Creative Commons), permissions for further reuse of content should be sought from the publisher or author. 
What remains of the intersubjective?: on the presencing of self and other

Paul Simpson

School of Geography, Earth and Environmental Sciences

Plymouth University

Plymouth

Devon, UK

PL4 8AA

Email: paul.simpson@plymouth.ac.uk

This is an Accepted Manuscript of an article published by Elsevier in Emotion, Space and Society on 19th May 2014 available at: http:// dx.doi.org/10.1016/j.emospa.2014.04.003 


\section{Abstract}

Recent work in the social sciences has been concerned with how we understand the subject. This has entailed critiquing the ways the subject has traditionally been understood - as a mental entity existing prior to and so organizing our experience of the world. In its place a relational subject has been posited, one emerging through a combination of affective experiences, performative enunciations, and haunting absent presences. However, the implications of such critiques for how we understand intersubjective relations have not been discussed. What remains of intersubjectivity when any subject entering into a relation has already been decentred amid a more-than human ecology of affective relations? In response, this paper draws on the work of Jean-Luc Nancy in developing understandings of the socio-spatial constitution of subjectivity/intersubjectivity in terms of movements of presencing. Here the bodysubject is always in approach to itself and others, but neither is actually reached, never (self) present, always already receding: a spacing at the heart of any relation. The discussion is interspersed with a series of narrative sections outlining an encounter between a street performer and their audience which draw attention to a number of key themes in any understanding of intersubjectivity and attempt to expose this inherent disposition.

Key words: Affect, Body, Intersubjectivity, Jean-Luc Nancy, Performance, Subjectivity. 


\section{Introduction}

This paper is interested in the centrality of bodily registers of experience to understandings of subjectivity and intersubjectivity. Whilst a range of critiques have recently been made of traditional understandings of the subject (see Dewsbury et al., 2002, Dewsbury, 2007, Harrison, 2000, 2008, McCormack, 2003, Pile and Thrift, 1995, Rose, 2006, Wylie, 2005, 2006, 2009), little has been written about the implications of these critiques for how we understanding intersubjective relations (though see Harrison, 2007a, 2007b). Such work has enacted "a transposition of the operations of subjectivity from the individual's head to a particular relation between self and world" (Rose, 2006, 546) and so understands the subject as "an assemblage composed of human and nonhuman materials" (Coward, 2012, 468). These compositions are permeated with affective relations and it is out of these that any such subjectivity emerges or devolves.

However, if we are to question the presence of an "I" that is static, that governs through "internal representational thought" (Rose, 2006, 546), and is self-present, and rather posit an "I" that is an "incessant coming-and-going" (Nancy, 1991, 98), emerging through "direct sensible impressions" (Rose, 2006, 546) and performative enunciations (Butler, 1999), this asks a number of questions about how we understand intersubjective relations. If the subject is not self-present, how can we be present to and for other subjects? What remains of the intersubjective when any such subject entering into a relation has already been decentred amid a more-than-human ecology of affective relations?

This paper approaches these questions through the work of Jean-Luc Nancy. Nancy's (1991, 1992) writings on community have recently gained interest in the social sciences (see Panelli and Welch, 2005, Popke, 2003, Rose, 1997). However, this paper will highlight the significance of Nancy's broader discussions of ontology as being singular plural (Nancy, 2000), being as being-with (Nancy, 2008a), and his co-existential 
analyses of subjectivity and the body (Nancy, 2008b), to thinking about the socio-spatial constitution of subjectivity and intersubjectivity (also see Bingham, 2006, Simpson, 2009, Welch and Panelli, 2007). These writings build on recent accounts of subjectivity in that they seek to understand the perpetual and ongoing emergence of subjectivity in terms of a movement of "presencing" and so approach an understanding of intersubjectivity that does not assume a self-present subject. However, they do so outside of the dichotomous tension of same and other, presence and absence, that is increasingly prominent in recent work rethinking subjectivity (see Harrison, 2007a, 2007b, 2008, Rose, 2006, Wylie, 2009). Nancy posits a "spacing" - a contemporaneous presentation and withdrawal between the self and the other in their relations with one another - at the heart of any relation and so an understanding of intersubjectivity ${ }^{1}$ based not on reciprocity, nor alterity, but on a singular plurality emergent in and through the being-with of bodies.

While primarily approaching these conceptual points, the paper is also interspersed with a series of narrative sections outlining an encounter from the author's ethnographic experiences of street performing in the UK. These narrative sections are intended to play a specific role in the paper. Rather than being "empirical data" analyzed in the development of a grounded theory of intersubjective relations, they are included, and at points reflected upon, as the events that unfolded that day are exemplary of, and give tangible form to, a series of themes of particular significance to the rethinking of intersubjectivity undertaken here and in Nancy's work. By including them, the paper seeks to give greater presence to the lack of assured self-presence that circulates through encounters between body-subjects; they draw attention to the exposure, dis-position, and

\footnotetext{
${ }^{1}$ Nancy's writings repeatedly insist on their distance from this term, especially as it is understood in its phenomenological variations (see Nancy 2000). Therefore, throughout the paper there will be an effacement of the commonplace understanding of intersubjectivity, and by implication subjectivity, by moving towards an understanding of the being-with of bodies as the basis for any such relation.
} 
lack of reciprocity in, and the inherent affective-corporeal nature of, intersubjective relations.

Following the narration of the initial moments of the encounter, section 2 turns to prominent critical discussions of subjectivity and relationality and articulates the original contribution of Nancy's work in relation to these. Following the further unfolding of the encounter, section 3 turns to conceptualizations of intersubjectivity and engages these in light of both the rethinking of subjectivity undertaken in Nancy's work and the issues raised by this event. The penultimate section of the paper concludes the encounter and section 4 concludes the paper by demarcating the space opened up for future thought around an affective understanding of subjectivity/intersubjectivity based on the being-with of bodies.

\section{The Encounter Part 1 - "I love you"}

I arrived in Broadmead, a central shopping area in Bristol, UK, around 1.10pm. It was very busy with workers on their lunch breaks. I set up to play outside a Tesco, opposite the entrance to the Galleries (an indoor shopping mall), and to the right of a Cornish Pasty shop. To my left, in the centre of the pedestrianized street, were some benches. To the right, again centre-street, some bike racks and a telephone box.

For the first 30 minutes people rushed about and didn't pay me much attention. However, once the lunch-rush receded things became a little mellower and I started to receive a little more attention. People were friendly and some stopped to chat. Some preschool aged children started to dance about in the street to the music I played while their parents talked. They smiled and, once the conversations stopped, waved as they walked away.

Around $2.00 \mathrm{pm}$ things changed. A man who looked rather worse for wear wandered into the pedestrian street-space. He was wearing shabby clothing, a large ill- 
kept full beard, a large bloody cut over one eye that couldn't have been more than a couple of days old. Generally, he looked as though he'd been sleeping rough and drinking. He had blood-shot skin around his cheeks and nose. He stopped dead at the other side of the street and, with a look of recognition, walked toward me. I was playing a bossa nova called "Signe". He arrived at my side of the street a little before I finished the song. Looking intently, he stood a few feet from me as I played the closing bars. As I finished he took another couple of staggered steps forward and lent to put money in my hat. I felt guilty. He looked like he needed the money more than me. However, rather than walk away or step back, he stood his ground and looked up. Without any warning he looked me in the eye and said: "I love you".

\section{Subjectivity - Saying "I love you"}

To say "I love you" is to mark a connection. Love is commonly taken to be about a union, an embrace, bonding, a coming together of individuals as one, unity, a completion of one by the other. A moment or duration of emotional, spiritual, and physical connection. Mutual and persistent presence between two selves.

In "Shattered Love" Nancy suggests something different. Nancy $(1991,92)$ does suggest that "[n]othing leads us more surely back to ourselves than love". However, he goes on to argue that the "I" does not return to itself from love as something of this "I" is lost or dislocated in the act of loving. Love here is about a fissure. A fissure between those who love and also a fissure in the lover him/herself. For Nancy (1991, 96), "[a]s soon as there is love, the slightest act of love, the slightest spark, there is this ontological fissure that cuts across and disconnects the elements of the subject-proper". Love "shatters" the self, transforms it. The I that loves and the I that is loved are not static substances but are constituted and transformed in and through love(ing). 
Such a (re)thinking of love is poignant here. It questions the stability of the self and the subject that loves or is loved. It highlights the unsettling nature of any declaration of love. Such a declaration constitutes the potential for an event, for change, in the sense of it marking "the encounter between two differences...contingent and disconcerting” (Badiou, 2012, 29).

Foregrounding this encounter of differences questions the status of the self as something that we can be present to, and especially as something present in advance of an encounter, proactively making sense of events as they happen. The initial encounter outlined above draws attention to a moment-by-moment shift in my sense of self and in my sense of that space. Throughout my time performing there "I" moved from feeling like a marginal and inconsequential feature of the bustling streetscape, to being uplifted by the reaction of those listening and their interest in the performance, to feelings of guilt and sympathy, to being taken aback and disorientated by the initial stages of the encounter with the man who said he loved me. That "I" was perpetually playing catch-up as it came to its self, at the same time as it was already moving away from itself, in the unfolding of this.

This latter encounter, and its subsequent unfolding in particular, is exemplary of what can be understood to be a situation of originary and ongoing dis-location of the self, and in turn a simultaneous dislocation of any other self. This "I love you" marked the inaugural moment of one particular sequence of affectual subjectifications whereby my self was differentiated from itself and from the self of this other. Thinking through this further opens onto an understanding of how separation is at the heart of any intimacy with both self and others, and so onto a particular take on "the spacing of what we all too easily call 'intersubjectivity"' (Harrison, 2007a, 593). 


\subsection{Presence and absence}

Decentring the autonomous subject in these terms raises a tension between the relative emphasis placed on presence and/or absence in the subject's relations to itself, others, and the world. This tension has become increasingly prominent in work seeking to reconceive the subject, particularly those influenced by Levinas and Derrida (Critchley, 1999, Rose, 2006).

Significant here is Wylie's (2009) discussion of the centrality of absence to the relations of subject and landscape. Often, especially in phenomenologically-inclined work, an emphasis is placed on the connections between self and landscape. Even in texts where a gesture towards non-coincidence is made, such as in Merleau-Ponty's (1968) account of the reversibility of touch and how there is never an absolute coincidence between touched and touching, there is, at least according to Derrida (2005), a "possiblein-principle coincidence of self with itself [auto-affection], and self with world" (Wylie 2009, 283). ${ }^{2}$ Wylie moves away from such a thinking of the ever-immanent coincidence of self with self and/or world as something that is possible (in principle, at least), and instead takes non-coincidence as a "constitutive absence or outside of the sensing body" (2009: 283). Non-coincidence becomes fundamental instead of just being incidental or a sign of a failure to relate. Rather than a connection between self and landscape, Wylie argues that self and landscape are dislocated from each other and that the self is haunted by an absence that formatively troubles its coherence. While the landscape may beckon a viewer, there is also a "faltering" in its appearance for that subject and so a lack of full disclosure or presence. This seeks to get away from the "metaphysics of presence" that haunts so much phenomenological work, and the implications of immersion and

\footnotetext{
${ }^{2}$ It is important to note that not all will agree with this assessment of Merleau-Ponty's position on self-other-world relations given his latter writings around "the flesh" and particularly his discussion of the reversibility of the flesh (Merleau-Ponty, 1968). For a range of takes on this aspect of Merleau-Ponty's work see Derrida (2005), Simonsen (2013) and Wylie (2006, 2009).
} 
involvement implied therein, by prioritizing the externalities, alterities, and absences that constitutively haunt the self.

Wylie talks of this specifically in relation to love and how love can be thought in terms of separation, distance, and rupture. Love here entails an exposure to the other whereby "[t]he gap, fracture or absence that is their origin equally and always entails an openness, an originary exposure of the self to externality and alterity" (Wylie, 2009, 284). Love is then about alterity in that the other is "inaccessible" and "inassimilable", something with which we can only ever fail to connect. Here, any claim to presence of self and other is "inviolated" by the troubling trace of the inassimilable other or outside. This means that there can be no coincidence between self and other and so there cannot be any "phenomenological fusion" between them. Rather, there is a simultaneous “opening-onto and distancing-from" (Wylie, 2009, 285), or what Wylie calls an absencing.

In contrast, this paper approaches the relations of self to itself, others, and world, as movements of "presencing". This is not just a case of semantic nitpicking. Such a move builds on the work just discussed in that it develops a thinking of social being outside of a "metaphysics of presence", but does so in a way which moves away from thinking of such relations in terms of the same-other dichotomy that much of this work, in its late-Derridean, and so Levinasian, heritage, is arguably grounded within. ${ }^{3}$ In Nancy's work the relation is given primacy rather than the alterity of the other, and so neither "the same nor the other is primary; rather both identity ('I') and (in)difference ('one') are derivative from a prior and unatomized 'we"' (Watkin, 2007, 52). This means thinking about subjectivity outside of a logic of gathering an enclosure (of the Same) without the need to posit an absolute (onto-theological) outside or radical

\footnotetext{
${ }^{3}$ An analysis of the relationship and influence of Levinas and Derrida and/on Nancy is beyond the scope of this paper. For more on this see Secomb (2006) and Watkin (2007).
} 
alterity/absence that would trouble or induce such a movement of gathering (Nancy, 2007a). Or as Nancy $(2000,34)$ states:

"what is at stake is no longer thinking:

- beginning from one, or from the other,

- beginning from their togetherness, understood now as the One, now as the

Other,

- but thinking, absolutely and without reserve, beginning from the 'with', as

the proper essence of one whose Being is nothing other than with-one-another".

It is a case then of beginning in the relation, in the middle, between the self and the other, in their being-with each other, rather than emphasizing the self or the other as having primary importance in the production of subjectivity. In turn, this starting point requires an attentiveness to the affective, subjectifying relations that proceed from our being-with others, a coming together of bodies (of matter, sound, meaning, sense, etc.).

\subsection{Co-existence and dis-position}

This move towards an emphasis on relations might at first appear to align Nancy's work with a range of other broadly relational accounts of human and more-than human coexistence. Perhaps most prominent here are the writings of Actor Network Theory (ANT) given its efforts to distribute agency and actancy amongst a heterogeneous parliament of things and to trace the associations between them by "render[ing] the social world as flat as possible" (Latour, 2005, 16 [emphasis in original]). In turn, of particular significance here is the way ANT's approach has influenced recent accounts of "strangers" (Amin, 2012). For Amin, the heterogeneity of modern Western societies means that we occupy space as gatherings of strangers. Importantly, whether "homegrown" or "foreign", our social dispositions towards (and as) such strangers are inflected 
by "the bodies, objects, technologies, legacies, ideas and imaginaries - tensely held together in relational space - that shape the affective proximities of humans to their worlds and with each other" (Amin 2012, 6). As such, the production of "the stranger" is very much a hybrid enterprise comprising a range of actants that exceed any straightforward categorization made according to a person's origin, conduct, or destination.

However, there is something specific to Nancy's appeal for an emphasis on relations that sets it apart from such discussions. To explain in more detail, Nancy (2000) presents a co-existential analytic which seeks to thematize the "with" as an essential trait of Being (Devisch, 2000). What is radical about Nancy's thinking of this "with" is that it does not presuppose what is relating or start with that which enters into a relation. Nancy does not posit a "flattened" unit of enquiry that enters into a relation (in the case of ANT, the actant) so as to trace the associations these enter into and are exhausted by. Equally, he does not emphasize the relative situation of separation/mutuality of such entities by designating them as "strangers" (or not). Instead, the relation itself is given primacy. And this is a particular form of primacy of a particular type of relation. As Nancy (2000, 34-35) states:

“' $t$ ]he one/the other is neither 'by', nor 'for', nor 'in', nor 'despite', but rather 'with'. This 'with' is at once both more and less than 'relation' or 'bond', especially as such relation or bond presupposes the preexistence of the terms upon which it relies; the 'with' is the exact contemporary of its terms; it is, in fact, their contemporaneity".

Subjects then are not atomized individuals and do not precede their relations (Coward, 2012). They are also not prescribed a specific situation prior to the relation's taking place, nor after. In the strict sense, they are not products of such relations or associations 
because they are never finalized, always exceeding them in some way. They are always already apart of relations-with others. I am not in relation, I do not enter into relations or associations, and nor do I emerge from them; I am relation.

Furthermore, as part of this, Nancy does also still talk about selves and bodies, of "the one" and of "the other", as well as "shells", "diamonds", "moons", "foams", "acids", "fingernails", "pollens", and so on, in distributing agency in this being-with (Nancy, 1993). There is, therefore, a much greater phenomenological inflection to Nancy's work, or better a post- or sensual-phenomenology (James, 2012; Harman, 2012), in his emphasis on this diversity of being-with the world. Or to put it another way, there is a much greater sense of topography here than in the flattened topology of ANT (Rose and Wylie, 2006); specific bodies, entities, and phenomena are given a particular but always emergent presence in the being-with of the world.

A central facet of Nancy's account of this contemporaneous being-with is that it is a relation of exposure in which something like a subject emerges; "the body consists in being exposed" (Nancy 2008b, 124). The subject, before it comes to be anything as fullyformed as that term suggests, is from the start exposed to what it is not and therefore is fundamentally impure (Devisch, 2002). This exposure is not a case of putting on display something that was previously hidden (an essence, for example) (Nancy, 1991). The "with" does not mark a sharing of a communal trait or of shared values. Rather "each one is exposed to the other, up against each other without being subsumed into each other" (Watkin, 2007, 59).

Such subsumption, or self-presence for that matter, is forestalled by a second central aspect of this understanding of being-with - a movement of dis-position or spacing. The subject co-appears and is dis-posed; the subject is a dis-position. The subject “persists only in its being-outside-of-itself” (James, 2006, 63) and so "[w]e are each time an other, each time with others" (Nancy, 2000, 35). Key here is Nancy's focus on the 
"dis" of dis-position. This "dis" forestalls any assured positioning or grounding of the subject in the world either in advance of any encounter or subsequently to it (Armstrong, 2009). In this spacing, the subject appears in a dual movement of presentation and withdrawal (James, 2006). The subject is always on the edge of, or in approach to, itself but it never arrives at any such stable ground of self-presence in its temporal unfolding of coming-to-presence and moving-from-presence. The subject "only appears insofar as it simultaneously disappears, it is posited as a 'punctual identity' which is without identity since it exists 'in a spasm which articulates and dismembers it, and only articulates it by dismembering it"' (Nancy cited in James, 2002, 135).

This again differentiates Nancy's account from the discussions of "strangers" mentioned earlier. Rather than emphasizing a state of being or a positioning as a stranger, either as an identity or as a product of a hybrid assemblage of relations (Amin, 2012), Nancy suggests something more akin to a movement of "estrangement". As Ahmed $(2000,92)$ notes, “The word 'estrangement' has the same roots as the word stranger. And yet, it suggests something quite different. It indicates a process of transition, a movement from one register to another". However, Nancy goes further than Ahmed is willing to in placing dis-position, this transitive estrangement, as a fundamental condition of our being-with the world. While Ahmed argues that such a universalizing of estrangement could cancel out social difference by making the experience of this common to all and so hiding different experiences of it, the emphasis in Nancy on the singular-plural nature of dis-positions actually radicalizes the difference present here. It means that all we have in common is that we are all undergoing our own unique, singular experience of the plurality of differings we are each perpetually moving through.

Therefore, the only essence that can be ascribed to our existence is of this disposition. Rather than maintaining some interiority or self-containment, we are dis-posed, de-posed, in our ongoing exposure to, or rather with, the world. Nancy does not 
articulate this as a displacement or deterritorialization from an originary position nor as a route to a position or a mechanism for positioning. Rather, it takes place as an originary ongoing and singular-plural dis-location and dis-connection from any relation or bond (Armstrong, 2009). Nancy "un-founds" the subject, allows it to "lose its isolated distinction of 'I"' $(2009,11)$, in this coming-and-going of the presencing of the self.

To bring this all back to the terms of the "encounter" initially outlined above, the statement "I love you" brought me to my "self", but, at the same time, did not bring me to full self-presence. It marked a particularly prominent moment in a movement from my "self", a dis-position. "I" was placed outside of my "self", dis-placed, in trying to make sense of the event that had just occurred. I was beside myself. His proclamation of love opened a fissure both between us and in my sense of self. This "I" was fractured and unsettled, dis-posed in trying to make sense of this proclamation. The encounter did not set in train some kind of shoring up of my sense of self by way of some reactive defense system. I was not consciously reflecting upon or able to shape my social subjectification in being enrolled in this relation as part of some form of care for the self (Foucault, 2005). Nor was I given "access" to my self as any access is a "coming to presence" and presence itself is, at the same time, the dis-position of a movement from self. All "I" had access to was the coming of this coming to presence, the coming itself, the transivity of the "I" (Armstrong, 2009). A feeling of being unsettled and unsure - of estrangement from myself - which brought about some sense of self, but a sense that was only ever provisional, partial, and unfolding.

\subsection{Affective dis-positions}

There was a quite visceral sense of dis-position here in this encounter that unsettled my sense of self. The being-with of bodies implies affective relations in that " $[t]$ he relation that is primary for Nancy is not a relation between substances existing independently of 
and prior to those relations (the ' $\mathrm{I}$ ' does not precede the 'we'), but being as relation, a being-in-common where being 'is' the in" (Watkin, 2007, 53). The self/other then is constituted in and as relation (James, 2012).

Nancy does not explicitly articulate a theory of affect. However, in his understanding of the being-with of bodies and the perpetual subjectification unfolding from this, bodies are permeated with sensuous, affective relations. Bodies hear, touch, taste, and smell (Nancy, 2008b). Bodies, in their originary exposure, are susceptible to the forces-filled materialities of the world (Nancy, 2007b). One way we can see this is in Nancy's discussion of emotion and commotion (Nancy, 2008b). For Nancy (2008b, 135), emotion means that a body is set "in motion, shaken, affected, breached". Developing this, commotion adds a specific emphasis on the "with" of being. The "co" in commotion refers to how a body is set in motion by its relations with... - any relation between bodies, or between bodies and world, sets in motion a process of subjectification, an opening of the body-self onto the future and to what it is not. The body for Nancy is not a closed unity but is opened onto the world, fundamentally exposed and affected by it - vibrating, resonating, trembling. Further, as we are always already in relation, this process is always already underway, without origin or destination, fully implicated in our being-with the world.

My orientation toward the world had already been affected, and was continuing to be affected, by, for example, my relations to the rhythms and routines of the street, the activities of the passersby who listened to me (or not), and my prior experience of performing in that space (and in other spaces) previously, not to mention an innumerable host of other relations present in that setting (see Simpson, 2013). Some of these affected me positively, others less so. This other had also clearly been shaped by his various and ongoing encounters with human and non-human others. Some of these encounters had literally wounded him, while the effects of encounters with other substances were clearly 
manifest in his bodily appearance and comportment. Such subjectifications were only ever going to be temporary, perpetually unfolding, in motion, in the playing out of our lives in this street. ${ }^{4}$

\section{The Encounter Part 2 - "When the Romans left Europe"}

Returning to that street, his proclamation left me speechless. However, he explained that he didn't want to cause offense, but that he loved what I was doing "like you would love a rainbow or a sunset". This made it a little less weird, but I still did not exactly feel comfortable.

He proceeded to tell me a large part of his life story. The context, I eventually figured out, was that he had lived in Spain and the song I had been playing sounded a little Spanish. He told me that he had lived in more than 20 countries and that he spoke numerous languages. He also told me a range of other details about his past. I wasn't too worried at this point given previous experiences of busking where "characters" would stop and talk. I simply nodded, didn't really offer much conversation, and hoped that soon he would get bored and leave.

However, he started to repeat himself. Each repetition started with the refrain: "Africa now is like when the Romans left Europe". Each repetition layered-in material that increasingly made me uncomfortable. He kept swearing, calling a selection of people “cunts", but straight after he would apologize for his language saying: "I don't mean to cause offense". This too was to become a familiar refrain. I was concerned as he was speaking rather loudly and I had spotted a number of disapproving looks from passersby.

\footnotetext{
${ }^{4}$ The question of a more substantial historicity to this complex relation between body, other, and world, and the implications of this to the unfolding of such subjectifications, is not something Nancy discusses in much detail. For a more detailed consideration of this in terms of how the "absent presence of historicity" impresses on specific bodies and inflects feelings and emotions see Ahmed (2004, 45).
} 
"Africa now is like when the Romans left Europe". He returned to talking about Spain, but this time told me about his brother who had moved there with him. He told me his brother had tried to marry a Spanish woman, but that her parents had tried to stop them because he wasn't Catholic.

"Africa now is like when the Romans left Europe". The cycling narration continued. He talked about racism and the state of Africa. He said he had grown up and lived a long time in Rhodesia and, although not advocating racist views per se, repeatedly used offensive language in that vein. I was now really wondering how to get away from him or to get him away from me. I couldn't think what to do. I could smell alcohol. Given the cut above his eye, I was concerned that he might become aggravated if I did something that he might construe as being rude. He looked as though he'd recently been in a fight. My discomfort wasn't helped when he mentioned that he'd been in the army and that they had ordered him to "shoot at those Kaffir cunts" but that he had deliberately missed as he didn't like racism.

Once more, "Africa now is like when the Romans left Europe". He returned to religion. Again we were back in Spain and his brother's experiences of Catholicism there. He said he liked African religions with many Gods, but didn't like atheists. He also said he didn't like judging people based on their religion. He asked if I was Irish, saying he'd only ever met one Irish person he didn't like who, again, was “a cunt”. I muttered my response and he asked again. I was now trying to make it clear I wanted to stop the conversation. I had deliberately made my responses stunted and had began to play my guitar a little to give him the (too) subtle hint that I wanted to play again rather than talk to him. Finally, I told him "I'm Scottish" and, to my relief, he said he liked Scottish people. 


\section{Intersubjectivity - Being-with others}

At this point I could move on to deconstruct the statements made in this further unfolding of my encounter to uncover what they meant and so provide a sort of "thick" description of the encounter and the significance therein. I could try to draw out connections between what was said and issues of religion, sectarianism, gender, politics in post-colonial Africa, and so on. In fact, following the encounter, I have spent some time wondering what was "actually" going on here, why the man really came over to me to say what he did, whether he really did mean to cause offense, and whether he was being deliberately provocative. I have wondered about what exactly he was getting at with his refrain: "Africa now is like when the Romans left Europe”.

Furthermore, I have wondered what my reaction to the encounter has told me about my self, what prejudices my reaction was based on in judging this 'stranger' (Ahmed, 2000), what role my apparent different socio-economic circumstances contributed to my perception of the man that approached me, or what sort of social contract and forms of political correctness common to my middle-class academic everyday life were being subverted (knowingly or not). I have been tempted to enact the archetypal social scientific gesture, the "quick jump to representational thinking and evaluative critique", and so attempt to ultimately explain away the affective, discomforting, and disconcerting nature of this encounter (Stewart, 2007, 4).

However, I want to approach the situation rather differently, and in a way that more closely befits both the actual playing out of the encounter as it happened and the post-phenomenological line of thinking being pursued in this paper. In many ways, what these words actually meant is a little beside the point. Rather than consider such intended meanings in a sort of retrospective analytical maneuver, I want to try to move towards what they did in terms of the processes of subjectification they affected in the event's unfolding. This was in fact strongly influenced by their very ambiguity and lack of 
immediate or transparent meaning. This lack was key to the way in which the world appeared to me in this moment. When I encountered this man it was the ambiguity of what he said, the fact that much of this came from no recognizable context that would aid my ability to understand it, that affected me most. It was the material-physicality of my exposure to his presence, and the atmospherics exuding from him, that set in motion my feelings of concern.

In considering these events in this sense, this discussion will linger a little at the surface of this encounter (Wylie, 2009), at the surface of the exposure and the disposition that occurred there at the point where the limits of one body came into contact with another (Abrahamsson and Simpson, 2011). That said, this will hardly be a stable ground to occupy.

\subsection{Reciprocity and otherness}

A central tension in the now substantial phenomenological literature on intersubjectivity is of particular significance here: the relationship between a common-being with the other and the other's "otherness" (see Busch, 1992, Harrison, 2007a, 2007b, Levinas, 1998). For example, in his account of dialogue Merleau-Ponty suggests that a common ground is constituted between the self and the other, their words being entered into a shared operation of which neither were creator. ${ }^{5}$ As Merleau-Ponty $(2002,413)$ states:

"In the experience of dialogue, there is constituted between the other person and myself a common ground; my thought and his are interwoven into a single fabric, my words and those of my interlocutor are called forth by the state of the discussion, and they are inserted into a shared operation of which neither of us is the creator. We have here a dual being, where the

\footnotetext{
${ }^{5}$ As mentioned earlier, the extent to which Merleau-Ponty's later work in 'The Visible and the Invisible' maintains this emphasis on reciprocity and presence has been questioned (see Simonsen, 2013).
} 
other is for me no longer a mere bit of behavior on my transcendental field, nor I his; we are collaborators for each other in consummate reciprocity. Our perspectives merge into each other, and we co-exist through a common world. In the present dialogue, I am freed from myself, for the other person's thoughts are certainly his; they are not of my making, though I do grasp them the moment they come into being, or even anticipate them. And indeed, the objection which my interlocutor raises to what I say draws from my thoughts which I had no idea I possessed, so that at the same time that I lend him thoughts, he reciprocates by making me think too."

Here a dialogue is collaboration. There is an emphasis on sharing and reciprocity. This could not be further from my experience of the exchange with my "other". There was nothing like collaboration or a feeling of sharing or reciprocity. Our thoughts were not "interwoven" nor did our perspectives merge in a common world. We did not produce a "mil-lieu [between place]" of meaning in which we were each immersed (Nancy, 2000, 5). There was an indeterminacy to the words spoken that lingered beyond the temporality of the encounter itself. The only thing being shared being a lack of sharing or commonbeing. This dialogue presented a "sharing out that remain[ed] at once a separation and an attachment, a parting of ways that open[ed] the space or spacing... of the in-common as such" (Armstrong, 2009, 180).

I previously stated that I did not come to my self in our initial encounter. Neither did I come to the self of the other in his declaration of love. In that moment he was not present to me. I in no way knew this other but rather was traversed by him and this proclamation; dis-placed from my self and dis-placed from his self. As the continued unfolding of the encounter shows, this dis-placement was ongoing. At no point did I feel like I had come to an understanding of this other person that faced me. My sense of self 
was rattled further. At no point did it feel like we occupied any sort of common ground. Equally though, the man that approached me was not absolutely other to me. It is not a question of an "other in general as the essential stranger who is opposed to what is proper, but of an alter, that is, 'one of the two'. This 'other', this 'lower case other', is 'one among many' insofar as they are many" (Nancy, 2000, 11).

Therefore, it is not only a question of who is this " $\mathrm{I}$ " that would know this other, as I have already suggested, but also who is this other "I"? If there is no singular "I" given prior to an encounter, then this asks serious questions about how we can understand intersubjective relations. We have to conceive this in the absence of any pregiven subject to be relating from or in relation to. It asks the question: how can intersubjectivity occur or be recognized when both "I" and the "other I" are perpetually unfolding and, therefore, are in our "selves" other to any "I" that I would have or the other would have? What happens when "[t]here never remains anything of the subject, since he [sic] is to be created on each occasion" (Deleuze, 2006, 87)? Or as Grosz (2001, 91) asks: 'What does it mean to reflect upon a position, a relation, a place [here the 'I'] related to other places but with no place of its own: the position of the in-between?”. All we are really left with is the "inter" of the intersubjective, the between, the with. As Nancy (2000, 5) surmises:

"Everything, then, passes between us. This 'between'... has neither a consistency nor continuity of its own. It does not lead from one to the other; it constitutes no connective tissue, no cement, no bridge. Perhaps it is not even fair to speak of a 'connection' to its subject; it is neither connected nor unconnected; it falls short of both; even better, it is that which is at the heart of a connection, the interlacing of strands whose extremities remain separate even at the very centre of the know. The 'between' is the stretching out and distance opened by the singular as such, its spacing of meaning”. 


\subsection{Bodies-with-bodies}

To move on from this potential impasse of thinking about intersubjectivity, one certainty here was that this was an encounter of bodies. There was a distinct corporeality to this encounter. As Nancy (2008b, 31) states, "I'll always know others as bodies. An other is a body because only a body is an other. It has this nose, that skin color, this texture, that size, this fold, tightness". Bodies here held a specific materiality: grimy, bloodied and bloodshot, wounded, and smelly; sweaty, tense, and saturated with adrenaline.

It is important though to distinguish this from the way certain idealist forms of phenomenology have understood the subject's relation to its body (see Husserl, 1988, 1989). It is not a case here of a self-present subject governing a body, bestowing sense upon its body, and also recognizing the other's body and its inner states empathically through a bestowal of sense. It is not then that there is first a subject and then intersubjectivity (Nancy, 2000). As Nancy $(2002,57)$ notes:

"the other is not second, does not come after. If the other, by the simple fact that I name it 'other', seems to presuppose the 'one' or the 'same', and thus only to come later, this is the effect of a still abstract thought that has penetrated neither into the one nor into the other. The one does not begin: it begins with the other".

The subject should be taken as a consequence of intersubjectivity rather than a condition for it (Armstrong, 2009). Here bodies are always with other bodies and such "bodies never stop selving" (Nancy, 2008b, 113). It is more about a circulation of sense in such encounters, a "transimmanent" sense as Nancy (1997) calls it, which is neither transcendental and given in advance of the experience, nor immanent and present within 
that which is experienced (see James, 2006, Simpson, 2009). A sense of self emerges in, through, and between such bodily encounters.

This account of sense again distinguishes Nancy's writings from a range of phenomenological work. For Nancy, sense refers to "the pre-symbolic meaningfulness of a shared bodily exposure to the world" which constitutes an "infinite excess of sense" rather than that perceived by the individual senses (James, 2012, 40). For anything to be or to exist, for anything to be perceptible or taken as an object of thought or experience, it has to in some sense make sense. This is not to say that it must be meaningful or have undergone conceptual determination. Rather sense means that "something like the transmission of a 'message' should be possible" (Nancy, 1997, 118). This is also not to say though that sense is disembodied here. While for Nancy the world always already makes sense in some way, "Sense and bodies are co-articulated in a fundamental way which discloses the world to us as existing" (James, 2012, 42). Nancy's postphenomenology of sense forms a more general pressing of "sense" as a "shared horizon of meaningfulness" (a 'world') beyond "the senses", taken here as forms of bodily sense perception directed towards a phenomenon. The former always exceeds the latter. This "touch" of sense as a being in "contact" with the world (as a shared horizon of meaningfulness) already make sense contemporaneously with any sensing in terms of the "sense of touch" (as tactility or vision) and so gives a very different account of world disclosure (James, 2012).

This, in turn, differentiates Nancy's writing on the body from those of MerleauPonty. As James (2012: 48) succinctly summarizes:

'the Nancean body-subject diverges in key ways from the 'body-proper' of Merleau-Ponty's phenomenology. Nancy's body, for instance, has no gathered unity or propriety since it is always exposed, projected outside itself, as it touches 
on the sense of the world. Bodily experience here is irreducibly fractured or fragmented".

In focusing on this particular take on corporeality, Nancy's understanding of the body emphasizes the affective couplings the body and its various parts are enrolled into. In many ways he echoes Deleuze and Guattari (2004) in their discussion of the body without organs and their related emphasis on the body not being a given totality or unity belonging to a subject, but rather an open-ended assemblage channeling intensive flows out of which a sense of subjectivity emerges as a point of accumulation. Nancy in fact makes direct references to this in a number of places (see Nancy, 2007b, 78). To take one example, Nancy notes that:

"a body is a collection of pieces, bits, members, zones, states, functions, heads, hands and cartilage, burnings, smoothness, spurts, sleep, digestion, goose-bumps, excitation, breathing, digesting, reproducing, mending, saliva, synovia, twists, cramps, and beauty spots. It's a collection of collections, a corpus corporum, whose unity remains a question for itself. Even when taken as a body without organs, it still has a hundred organs, each of which pulls and disorganizes the whole, which can no longer manage to be totalized" (2008b, 155).

In their combination, these and other bodies produce a singular "affective discharge". Such discharges act to both dilate and contract the body, to positively and negatively affect it. In its interactions, the body both "becomes distressed (tightens) and it rejoices (dilates)" (Nancy, 2007b, 43). Such tightening, a closing in upon itself, can be seen as a negative affect whereby the body (unsuccessfully) seeks to remove itself from its interactions from the world and in dilating, the opposite takes place - it is positively 
affected by its interactions, increasing its capacities and potential for interaction, and increasing of its ek-stasis, its being beyond itself.

To return once more to the encounter, this was initially an affective bodily coupling of ear, sound, eye, clothing, beard, skin, wound, nose, breath, and so on, in the body's pre-reflexive dis-position with the world. The connection resulted in the consummation and "resonance" of the intensities channeled. Out of this resonance a “trembling" sense of my self emerged in being discomforted and unnerved (Nancy, 2002, 2007b). The materiality - corporeal, olfactory, sonorous - encountered through this bodily exposure was disconcerting. I felt disgust and recoiled from the risk of contamination from my close exposure to aspects of the other's materiality (Ahmed, 2004). There was a contraction, a distressing of my corporeality, an impulse emerging from these affective discharges that pushed me towards withdrawing from this relation. It brought us together but in doing so moved us apart given the way my fear produced "shudders...felt on the skin, on the surface that surface[d] through the encounter" (Ahmed, 2004, 63). I wanted to get away but couldn't think of a way to do so. My capacities for thought and action where reduced. At the same time a sense of this other emerged as a person who was likely sleeping rough and drunk through this consummation and resonance. Such subjectifications will have also played out for this other, though I was not party to them. They appeared to me as somewhat more positive than those I was undergoing, the sound of my music setting in train a range of recollection and reflections for him.

There was then "a becoming otherwise of each of the terms thus bounded" in this greater emphasis on creative inter-relation and the "in-between" (Grosz, 2001, 65). As Secomb (2006, 458) notes, "[e]ach and every encounter...inaugurate[d] us as singularities, touched and constituted through this plurality". A sense of this other, a whole not given or final, emerged from this bodily interrelation, rather than through my 
empathic recognition of him as a pre-existent behaving other. This emergence of the other continued and, in many ways, still continues as I write this. In this emergence there is contiguity but not continuity of the relating bodies as "the law of touching is separation" and so "[i]f to 'come into contact' is to begin to make sense of one another, then this 'coming' penetrates nothing; there is no intermediate and mediating 'milieu"' (Nancy, 2000, 5).

While it could be argued that this spacing of our subjectivities does leave open the solipsistic question around the knowledge of the presence of other subjects that has been so central to understandings of intersubjectivity (Husserl, 1988, Zahavi, 2003), it does in fact infinitely defer the question. The subject will always be coming, but yet to come, in its bodily being with other bodies; "the coming never ends, it goes as it comes, it's a coming-and-going" (Nancy, 2008b, 65). As Nancy (2002, 58) makes clear, "the other takes leave of itself in the same movement as the one".

\section{The Encounter Part 3 - "I don't mean to cause offense”}

Again, the Romans were leaving Europe, but this time they were interrupted. Midsentence he broke off and blurted: "The thing is, the solution is, everyone should masturbate, I mean, you think they don't? You think the Queen doesn't? Everything would just be better. Sorry. I don't mean to cause offense”.

At this point I'd come to the end of my tether and needed to leave.

I said "Right" and looked away. He again repeated he didn't mean to cause offense, and quickly said he was going to the pasty shop and asked if I wanted anything. I declined but he continued: "they're very good". I said I'd already eaten. After more of this sort of back and forth he gave up.

I now saw my way out. When he was in the pasty shop, which would only be for a minute or two, I was going to leave. Before leaving for the pasty shop he said: "you 
won't mind if I sit there (beside me) and listen do you?". I didn't get the chance to answer - he was walking away almost before he finished his question.

As the man turned the corner I was reaching to switch off my amp and detach my guitar lead. However, just as I did so an elderly woman I'd seen listening earlier came over, put money in my hat, and asked if I was a student. She then, very slowly, started trying to remember what her son had studied. She muttered to herself: "was it Maths or Physics, no, maybe it was Chemistry, no it was definitely Maths, or was it...", almost suggesting I should be able to help in her decision.

I could see the man coming back.

He came over and stood to my left. The lady noticed him lingering and said: "I hope you're going to put something in his hat". He responded saying he had and that we were friends. Upon hearing this, she gave me a rather suspicious and disapproving look then left hurriedly. Rather than play on or talk more - 10-15 minutes had been more than enough - I simply said: "Sorry, I've just realized the time. I need to go meet someone". I wasn't going to give any more or less detail or change from this line. I didn't want to stay there any longer, even if he did sit quietly. I just wouldn't feel comfortable and he would in all likelihood try to chat more.

As I packed up I could feel my heart pounding. I was trying to pack as quickly as possible but not to look as though I was. I fumbled to put things away. As I did so he made mumbled comments about "everything having its place, sorry, I don't mean any offense". I then said bye and he said "nice talking to you friend" and put out his hand. I really didn't want to shake it, but I did. Possibly the shortest and loosest handshake of my life. 


\section{Conclusion}

This paper has tried to think through the ways in which intersubjective relations play out in light of the decentering of the autonomous subject amid an ecology of affective relations. Drawing on the work of Jean-Luc Nancy, and by outlining one exemplary (if extreme) encounter, it has tried to re-present some of the dis-posing exposure that takes place as part of this and so the ongoing co-subjectification that proceeds from it.

Upon reflection, I am fairly certain that this man wanted nothing more than to simply be my friend and, as repeatedly stated, didn't intend any offense. Whatever his intentions were, and despite the actual meaning intended by his repeated and ambiguous comments, throughout this encounter there were the very real, very material impacts of the encounter on my bodily being. As the events unfolded, my mind raced, my palms sweated, my heart pounded. I didn't know what to do and struggled to form a plan to get away. I never reached a clear or assured sense of what was going on. Time seemed to move so slowly. The inter-corporeal encounter with this man, though largely not involving physical contact, touched me. It had direct material implications for my body and for my sense of self and the world. "I" was most definitely unsettled, dis-posed from the position "I" occupied before his arrival.

While the encounter focused on here had its own singular character of discomfort and unpredictability, there are elements present it in that are common to any encounter. It was simply the case that these common elements - of exposure, spacing, disposition, corporeality - were particularly amplified on this occasion. As mentioned earlier, processes of affective subjectification proceeded from a multiplicity of relations in my performing that day, they just largely failed to make quite such an explicit deforming impression on my sense of self. In the humdrum of our everyday lives we are always already enrolled in a range of affective, subjectifying relations with the world. Bodies of 
varying shape, size, materiality, and vibrancy co-appear with us. On that day, this background being-with the world broke through the threshold of my consciousness.

In sum, this paper has attempted to open up a space in which to think about a post-foundational account of intersubjectivity and what this might look like, and particularly to do this outside of a certain logic of same and other, absence and presence, which has come to permeate recent discussions of subjectivity and intersubjectivity. There are two central features of this.

Firstly, this move entails an emphasis on material relations between bodies (and the world more generally) which "selve" in their singular-plural being-with other amid the shared horizon of the sense of the world. These bodies are not to be conceived of as being governed by a Subject which empathically recognizes the other and communes with them, nor a subject called into being by an absolute Other. This originary sociality does not mean that there is a shared origin or unity in community as there is no origin or ground to be shared. Rather, it is a body that is productive of subjectivity in its exposure, in its being-with other bodies.

Secondly, this logic of the being-with of bodies and world entails an open-ended sort of subjectivity that is perpetually emergent in its ongoing and always plural beingwith bodies. Bodies and selves are always already dis-posed, in co-motion. The self is always emerging as a dis-position where "[i]ncompletion is its 'principle,' taking the term 'incompletion' in an active sense...as designating not insufficiency or lack, but the activity of sharing, the dynamic, if you will, of an uninterrupted passage through singular ruptures” (Nancy, 1991, 35). Presencing. Coming-to-presence. Spacing.

\section{References}

Abrahamsson S, Simpson P. "The limits of the body: boundaries, capacities, thresholds." Social and Cultural Geography 12 (2011): 331-8.

Ahmed, S. Strange Encounters: Embodied Others in Post-Coloniality. Routledge: London, 2000. Ahmed S. The Cultural Politics of Emotion. Edinburgh: Edinburgh University Press, 2004. 
Amin A. Land of Strangers. Polity: Cambridge, 2012.

Armstrong P. Reticulations: Jean-Luc Nancy and the Networks of the Political. London: University of Minnesota Press, 2009.

Badiou A. In Praise of Love. London: Serpent's Tail, 2012.

Bingham N. "Bees, butterflies, and bacteria: biotechnology and the politics of nonhuman friendship." Environment and Planning A 38 (2006): 483-98.

Busch TW. "Ethics and Ontology: Levinas and Merleau-Ponty." Man and World 25 (1992): 195-202.

Butler J. Gender Trouble. London: Routledge, 1999.

Coward M. "Between us in the city: materiality, subjectivity, and community in the era of global urbanization." Environment and Planning D: Society and Space 30 (2012): 468-81.

Critchley S. Ethics-Politics-Subjectivity: Essays on Derrida, Levinas, and Contemporary French Thought. Verso: London, 1999.

Deleuze G. Foucault. London: Continuum, 2006.

Deleuze G, Guattari F. Anti-Oedipus: Capitalism and Schizophrenia. London: Continuum, 2004.

Derrida, J. (2005) On Touching - Jean-Luc Nancy. Stanford University Press, Stanford.

Devisch I. "A Trembling Voice in the Desert: Jean-Luc Nancy's Rethinking of the Space of the Political." Cultural V alues 4 (2000): 239-56.

Devisch I. "Being mondaine: Jean-Luc Nancy's Enumerations of the World." Cultural Values 6 (2002): 385-94.

Dewsbury J, Harrison P, Rose M, Wylie J. "Introduction: Enacting Geographies." Geoforum 33 (2002): 437-40.

Dewsbury JD. "Unthinking subjects: Alain Badiou and the event of thought in thinking politics." Transactions of the Institute of British Geographers 32 (2007): 443-59.

Foucault M. The Hermeneutics of the Subject: Lectures at the College de France 1981-1982. Basingstoke: Palgrave Macmillan, 2005.

Grosz E. Architecture from the Outside: Essays on Virtual and Real Space. London: The MIT Press, 2001.

Harman G. On Interface: Nancy's Weights and Masses. In Jean-Luc Nancy and Plural Thinking: Expositions of World, Ontology, Politics, and Sense, Edited by Gratton P, Morin M-E, New York: SUNY Press, 2012.

Harrison P. "Making sense: embodiment and the sensibilities of the everyday." Environment and Planning D: Society and Space 18 (2000): 497-517.

Harrison P. "'How shall I say it?' Relating the non-relational." Environment and Planning $A$ 39 (2007a): 590-608.

Harrison P. "The space between us. Opening remarks on the concept of dwelling." Environment and Planning D: Society and Space 25 (2007b): 625-47.

Harrison P. "Corporeal Remains. Vulnerability, proximity and living-on after the end of the world." Environment and Planning A 40 (2008): 423-45.

Husserl E. Cartesian Meditations: An Introduction to Phenomenology. Dordrecht: Kluwer Academic Publishers, 1988.

Husserl E. Ideas pertaining to a pure phenomenology and to a phenomenological philosophy. London: Kluwer Academic Publishers, 1989.

James I. “The Persistence of the Subject: Jean-Luc Nancy.” Paragraph 21 (2002): 125-41.

James I. The Fragmentary Demand: An Introduction to the Philosophy of Jean-Luc Nancy. Stanford: Stanford University Press, 2006.

James I. The New French Philosophy. Cambridge: Polity, 2012.

Latour B. Reassembling the Social: An Introduction to Actor-network-theory. Oxford:

Oxford University Press, 2005. 
Levinas E. Otherwise Than Being Or Beyond Essence. Pittsburgh: Duquense University Press, 1998.

McCormack D. "An event of geographical ethics in spaces of affect." Transactions of the Institute of British Geographers 28 (2003): 488-507.

Merleau-Ponty M. The Visible and the Invisible. Evanston: North Western University Press, 1968.

Merleau-Ponty M. Phenomenology of Perception. London: Routledge, 2002.

Nancy J-L. The Inoperative Community. Minnesota: University of Minnesota Press, 1991.

Nancy J-L. 'La Comparution/The Compearance: From the Existence of 'Communism' to the Community of Existence." Political Theory 20 (1992): 371-98.

Nancy J-L. The Birth to Presence. Stanford: Standfor University Press, 1993.

Nancy J-L. The Sense of the World. London: University of Minnesota Press, 1997.

Nancy J-L. Being Singular Plural. Stanford: Stanford University Press, 2000.

Nancy J-L. Hegel: The Restlessness of the Negative. Minneapolis: University of Minnesota Press, 2002.

Nancy J-L. The Creation of the World or Globalization. Albany: SUNY Press, 2007a.

Nancy J-L. Listening. New York: Fordham University Press, 2007b.

Nancy J-L. "The being-with of being-there." Continental Philosophy Review 41 (2008a): 1-15.

Nancy J-L. Corpus. New York: Fordham University Press, 2008b.

Nancy J-L. The Fall of Sleep. New York: Fordham University Press, 2009.

Panelli R, Welch RV. "Why community? Reading difference and singularity with community." Environment and Planning A 37 (2005): 1589-611.

Pile S, Thrift, N. Mapping the Subject. London: Routledge, 1995.

Popke EJ. "Poststructuralist Ethics: subjectivity, responsibility and the space of community." Progress in Human Geography 27 (2003): 298-316.

Rose G. Performing Inoperative Community: the space and the resistance of some community arts projects. In Geographies of Resistance, Edited by Pile S, Keith M, London: Routledge, 1997.

Rose M. "'Gathering dreams of presence': A project for the cultural landscape." Environment and Planning D: Society and Space 24 (2006): 537-54.

Rose M,Wylie J. "Animating landscape" Environment and Planning D: Society and Space 24 (2006): 475-479.

Secomb L. "Amorous Politics: Between Derrida and Nancy." Social Semiotics 16 (2006): 449-60.

Simonsen K. "In quest of a new humanism: Embodiment, experience and phenomenology as critical geography." Progress in Human Geography 37 (2013): 10-26.

Simpson P. "Falling on deaf ears': a post-phenomenology of sonorous presence." Environment and Planning A 41 (2009): 2556-75.

Simpson P. "Ecologies of Experience: Materiality, Sociality, and the Embodied Experience of (Street) Performing." Environment and Planning A 45(2013): 180-196.

Stewart K. Ordinary Affects. London: Duke University Press, 2007.

Watkin C. “A Different Alterity: Jean-Luc Nancy's 'Singular Plural'.” Paragraph 30 (2007): 50-64.

Welch RV, Panelli R. "Questioning community as a collective antidote to fear: Jean-Luc Nancy's 'singularity' and 'being singular plural'." Area 39 (2007): 349-56.

Wylie J. "A single day's walking: narrating self and landscape on the South West Coast Path." Transactions of the Institute of British Geographers 30 (2005): 234-47.

Wylie J. "Depths and folds: on landscape and the gazing subject." Environment and Planning D: Society and Space 24 (2006): 519-35.

Wylie J. "Landscape, absence and the geographies of love." Transactions of the Institute of British Geographers 34 (2009): 275-89. 
Zahavi D. Husserl's Phenomenology. Stanford: Stanford University Press, 2003. 